Khalid Mourigh*

\title{
A dutch multiethnolect? Metalinguistic commentary from Gouda
}

https://doi.org/10.1515/applirev-2017-0053

Abstract: It is assumed that there exists a multiethnolect in the Netherlands that is used by Dutch youth with different heritage backgrounds. It is lexically mainly influenced by Sranan Tongo while phonetically it is mainly influenced by a Moroccan Dutch accent. In this article, I will argue, based on metalinguistic comments given in interviews, that Moroccan Dutch youth speech in the city of Gouda departs from this conception of multiethnolect. Interviews with Moroccan Dutch teenagers there reveal that, in their youth variety, Sranan Tongo lexical items are not readily accepted and used. In addition, their perception of Straattaal differs from the perception of their Indigenous Dutch peers in Gouda. In this way, a different light can be shed on multiethnolect in the Netherlands.

Keywords: multiethnolect, Moroccan dutch, Straattaal, Gouda

\section{Introduction ${ }^{1}$}

In recent years, emerging youth varieties of Dutch have been the subject of a number of studies, adding to the ever-growing body of literature on youth varieties. A topic that has been the subject of particular debate is the question of how to categorize these youth varieties, and which label is the most appropriate for them. Depending on the approach taken, different terms such as ethnolect, multiethnolect and urban youth speech style have been proposed (cf. Aissati et al. 2005; Nortier and Dorleijn 2008; Nortier and Dorleijn 2013; Dorleijn et al. 2015; Cheshire et al. 2015). In the case of Dutch, it is generally assumed that two different heritage language groups, namely Caribbean Creole languages and Moroccan languages, have been the main source of influence on the current

1 I would like to thank Maarten Kossmann, Jacomine Nortier and Margreet Dorleijn for their valuable comments and input. Of course, this article could not have been written without the cooperation of many people in Gouda. The research was done within the framework of Advancing the European Multilingual Experience (AThEME): http://www.atheme.eu/.

*Corresponding author: Khalid Mourigh, Leiden University Center for Linguistics, Leiden, The Netherlands, E-mail: k.mourigh@hum.leidenuniv.nl 
youth varieties (Dorleijn et al. 2015: 273). ${ }^{2}$ On the one hand, there are varieties in which the lexical component mainly originates from Sranan Tongo (Surinamese creole), and to a lesser extent from English, Moroccan and Turkish languages (Appel 1999; Appel and Schoonen 2005). These varieties are generally referred to with the rather vague term Straattaal ('street language', cf. Appel 1999; Nortier 2001; Appel and Schoonen 2005; van Lier 2004; see also Kossmann, this volume; Nortier, this volume), although this term is problematic; for the speakers it can refer to multiple phenomena, as will become clear in this paper (cf. Cornips and de Rooij 2013: 138 for a discussion). On the other hand, there are varieties of which the accent is the most influential. This accent has its roots in the pronunciation of Dutch by Moroccan-Dutch teenagers, and is reported to be extremely dynamic and spreading (Nortier and Dorleijn 2008: 128). This variety is referred to by Nortier and Dorleijn as Moroccan Flavored Dutch (MFD) (Nortier and Dorleijn 2008: 127). All in all, the general idea is that there are two separate categories of youth varieties in the Netherlands: on the one hand Straattaal, and on the other MFD. Following Kossmann (this volume) I will adopt the terms DSL "Dutch with Surinamese Lexicon" for the Sranan Tongo-based Straattaal variety and DML, "Dutch with Moroccan Lexical elements" for the Moroccan-influenced variety, because in this paper the lexicon and not the accent will be the central focus.

DSL and DML together have been described as a "multiethnolect" (Nortier and Dorleijn 2008; Nortier and Dorleijn 2013; Muysken 2013; van Meel 2016). However, the term multiethnolect itself is not uncontroversial. Cheshire et al. (2015) recognize the problems with the use of the term multiethnolect, but for the lack of a better term they ultimately decide to adopt it, stressing that "[w]e use the term with caution, recognizing that ethnicity may no longer be a relevant social factor and without wishing to reify a way of speaking that is dynamic and far from focused.” (Cheshire et al. 2015: 5). While there is no doubt that youth varieties are inherently dynamic and constantly developing and there is always the danger of reification, I propose that a central assumption underlying the term multiethnolect, namely the ethnic component, may be much more robust than proposed. While ethnic boundaries may be easily crossed in multiethnic neighborhoods and may lead to the emergence of new varieties, this is not necessarily always the case. In this article, I present data that illustrates a different point of view, namely of the speakers of DML in the city of Gouda. Gouda is a small city in the western region of the Netherlands, and has the highest percentage of Moroccan Dutch (Dutch speakers with Moroccan heritage background) in the

2 In addition, there are elements which originate for other languages such as English, Turkish, Papiamentu. 
Netherlands. Other ethnic minority communities, such as Turkish or Surinamese Dutch, are very small in Gouda. For this reason, Gouda is an interesting place to study the dynamics of the Moroccan input languages for the Dutch multiethnolect. Metalinguistic data show that in this community where Moroccan Dutch and Indigenous Dutch are the only relevant ethnic groups, the youth variety is more monolithic than has been argued for the general Dutch multiethnolect (cf. Kossmann this volume for the term "Indigenous Dutch"). Therefore, I will argue that the youth variety in Gouda is only influenced by the Moroccan heritage languages and as a consequence, it is not part of a "multiethnolect". Although the way people talk is a central focus of sociolinguistic studies, this paper strongly supports the view that for a more complete understanding it is necessary to pay attention not only to the linguistic form but also to the social use and ideology of the speakers, in other words "[the] metapragmatic activities in which they create and circulate ideas about how they talk" (Johnstone et al. 2006: 99). A fuller picture of the "total linguistic fact" (Silverstein 1985) may help the researcher to understand the direction of the development in a process of ongoing language contact. One purpose of this article, therefore, is to show that metalinguistic discourse can be a major tool in the interpretation of linguistic practices and will reveal insights that remain hidden when using other research methods. To this end, metalinguistic comments on the lexicon, which are more frequently issued than comments on, for example, pronunciation, will be used to uncover linguistic ideologies. It is both the formal and functional viewpoints which serve as a lens to examine the use of the lexicon by Moroccan Dutch and Indigenous Dutch participants (cf. Lemon 2002 for form and function; Schluter, this volume, and the introduction to this volume).

For the purpose of examining this question, an emic perspective of ethnicity and youth language will be adopted. In this way, ethnicity is understood from the viewpoint of the speakers themselves (van Meel 2016: 58). In this article I will come to similar conclusions as Kossmann (this volume) who argues that Moroccan Dutch heritage speakers do not adopt DSL on an ideological level, in the sense that they dissociate themselves from Surinamese or a "black" ethnicity in general. However, the situation in Gouda is different also on a practical level, as the speakers in Gouda mostly avoid using DSL. Thus, the focal point of this paper is the perceived ethnic boundary and not the process of identity formation, which is inevitably multi-faceted and fluid. Furthermore, it turns out that another boundary established by the Gouda Moroccan-Dutch teenagers is between "us" (Gouda) and "them": big-city dwellers in Rotterdam and Amsterdam.

I will first turn to a description of the population studied and the methods used. Following that, I discuss the use of DML. How DML and DSL are 
enregistered and how locality is constructed are the subject of Section 4. The borrowing of DML by non-Berber speaking groups and the ensuing spread of DML will be discussed in the final section.

\section{Population and methods}

In 2016 the total population of Moroccan Dutch in the Netherlands was 385,761 (CBS 2016). The majority live in the big cities in the west of the country: the highest concentrations of Moroccan Dutch people live in large multicultural cities like Amsterdam, Den Haag and Rotterdam and Utrecht. Gouda, which is a relatively small city with 71,105 inhabitants, has the largest proportional population of Moroccan Dutch in the country with 6,892 members, of whom the highest concentration live in the neighborhood Oosterwei (CBS 2016). ${ }^{3}$ About half of the Moroccan Dutch population in Gouda belong to the second generation, meaning that they were born in the Netherlands and have at least one parent who was born in Morocco. According to the people interviewed in Gouda, most members of the local Moroccan community originate from the region of Nador in North Morocco, more specifically from the area of Ayt Said. This means that a large percentage of its members have Tarifiyt Berber as their heritage language (98,5 \% of the population from the countryside of Ayt Said speak Tarifiyt Berber, HCP 2016). Dialectal Arabic also plays an important role as a lingua franca in general. Furthermore, while Standard Arabic is not used for everyday communication, it still plays an important role in religious life and in the media. People who were born and raised in the Netherlands mostly use Dutch in daily life (already in 1980s, cf. de Ruiter 1989). With their parents, they often speak Berber or (dialectal) Arabic, or they code-switch between one of these languages and Dutch. Therefore, Berber and Arabic can be considered heritage languages (cf. Montrul 2016).

The present study is based on a corpus consisting of interviews conducted by the author with Moroccan Dutch and Indigenous Dutch teenagers in 2014, 2015 and 2016. The full corpus consists of roughly thirteen hours of interviews with thirty-one people. All interviews were conducted with groups of at least two people (not including the interviewer). Speech was recorded using a professional

3 Other non-western immigrant groups are much smaller in Gouda. The second largest immigrant group are the Indonesians which consists of 1,599 people, followed by Germans (963), Surinamese (922), and Poles (629). Turks, another large immigrant group in the Netherlands, are represented in Gouda by only 459 people (CBS 2016). 
recording device. The length of the interviews ranged from five minutes to one and a half hour. Two teenage girls from the same background as the male subjects and three older first generation men (born and raised in Morocco) were interviewed. The teenagers share a similar socio-economic and educational background. They attended either secondary school (VMBO) or lower vocational training (MBO). The interviews were conducted at different places in informal settings such as the hallway of a sports club, a cultural center, close to the school and in the town center. All interviews were conducted in Dutch with occasional code-switching to Tarifiyt Berber or Arabic. In general, the interviews started with questions about the use of Straattaal. It is from these parts of the interviews that most of the metalinguistic comments in this article originate. The interviews were transcribed in ELAN. ${ }^{4}$ The specific data included in this article is from interviews with twelve young males and one young female of Moroccan Dutch heritage and four young males of Indigenous Dutch heritage between the ages of 15 and 21.

The interviews inevitably suffer from the observers' paradox: even though the interviewer shares the ethnic background of the interviewees, he does not share other characteristics such as age and place of residence. The interviewees gave the impression of being quite comfortable, however the lack of certain lexical elements, such as Berber and Arabic discourse markers, which are typical for Moroccan Dutch discourse indicate that their speech was somewhat influenced by the presence of the interviewer (cf. Kossmann fc). One way to overcome this problem is to explore the metalinguistic knowledge of the speakers. Speakers in multilingual settings often know very well which type of language they use in different situations.

\section{DML in Gouda: Usage}

For the young Moroccan Dutch informants in Gouda the main heritage language is Tarifiyt Berber. It is from this language that most lexical items are drawn when a respondent is asked to provide an example of Straattaal. Therefore, for them, Straattaal means something else than for Appel and Schoonen (2005: 85-86) who define it as a variety with input from heritage languages and "new" Dutch words - "existing Dutch words with new meanings" (Appel and Schoonen 2005: 85-86), in other words, a style or a mixed multiethnolect with input from different varieties which can be used variably depending on the context. The

4 https://tla.mpi.nl/tools/tla-tools/elan/ 
term Straattaal remains rather vague in its reference. It will be shown that for Indigenous and other Dutch speakers it means something else than for the Moroccan Dutch informants (see also Kossmann, this volume).

Examples of lexical items provided by the respondents include təzz $x a \check{s}^{5}$ 'shame on you', ašəkkam 'traitor', zzaməř 'faggot', buyizzan 'shit person', șaaf 'money', hawař 'watch out', qəwwad 'get lost!' which are all clearly recognizable Berber lexical items. ${ }^{6}$ This gives rise to the question of whether these are instances of code-switching. However, while code-switching is certainly part of DML discourse, the list of lexical items provided by the respondents as being typical for DML is very limited. In addition, and more importantly, these words are used by Moroccan Arabic heritage speakers as well. This is an indication that the Berber words of DML are spreading. Another conspicuous element of DML discourse is the use of interjections and function words, which derive from Berber and Arabic, such as wallah 'lo!', tazz= expression of disapproval, §әуyəq 'very', ižžən=indefinite article, $a / y a=$ exclamatives, $w a \check{\text { s }}$ question particle, zəSma 'like' (cf. Kossmann fc, Nortier and Dorleijn 2008: 130).

It is striking that the Moroccan Dutch speakers never refer to any DSL items when asked about their Straattaal. When asked what is typical about their Straattaal, one speaker confirms that Berber lexical items constitute the lexical pool on which Gouda Straattaal is based.

MM/2: Die tmazight is eigenlijk onze Straattaal.

'That Berber is actually our Straattaal.'

In example (2), the speaker continues his answer in which he establishes two points: his knowledge of the form of DSL and the playfulness of his language use. Again he gives an example of the way in which the Moroccan Dutch youngsters speak by using the DML elements yallah 'come on' and ar mani 'where to?'. The phrase is then turned into a pun, so that it sounds like 'Armani' the famous fashion brand.

5 In the examples words with a non-Dutch background are marked by underlining. When discussing non-Dutch and non-English words, standard orthography is followed for Sranan and Papiamentu. Moroccan Arabic and Berber are written phonologically. Following practices in the

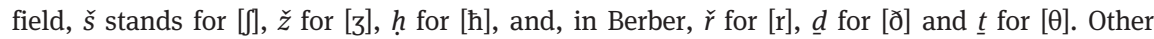
consonants with a dot underneath are pharyngealized.

6 Many of the examples are originally borrowings from Moroccan Arabic, but can be identified as Berber because of specific phonetic changes, e.g. $1>\check{r}$ as in Arabic zamal which has been borrowed into Berber as zzamər. 
(2) $\mathrm{MM} / 2$ : Wij zijn niet echt gewoon, je weet toch, nee het is niet: he faka brada, mi waka richting die kant, je weet toch, dat hebben wij niet.

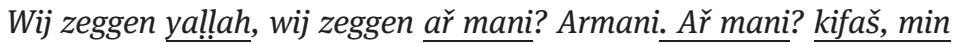
toggad ? Waar jij? Que? Waar jij?

We don't have like, you know: he faka brada (what's up, brother). mi waka (I walk) in that direction, you know, we don't have that. We say: yallah (come on). We say: ař mani (where to). Armani. Ar mani (where to), kifaš, min tagga $\underline{d}$ (how, what are you doing)? Where you? Que? Where you?

The Straattaal lexical items faka 'what's up' (a shortened form of fawaka), brada 'brother' and mi waka 'I walk' in (2) are based on Sranan. This speaker provides a number of possible alternatives: yallah 'come on' is a Moroccan Arabic/Berber expression. Ař mani 'where (are you going) to' is another informal greeting, here with a pun on the fashion brand Armani. The pun seems to be more generally known, and was heard by the author in Utrecht as well. Kifaš, min təgga d 'how, what are you doing' is another Berber expression, while Spanish que, 'what', (often used in Berber discourse in Nador in Morocco) and illie ('illegal') Dutch waar jij, 'where you', constitute further alternatives. Illie is what the stereotypical Dutch speech by recent immigrants from Morocco is called, as opposed to the native competence of the people who grew up in the Netherlands (cf. Jaspers 2004).

The question then arises of whether DSL is totally absent in Gouda. The answer is negative: it seems to be present in Gouda indeed, in a different form and surprisingly, as one speaker indicates, it is mostly used by the Indigenous Dutch in Gouda. The Moroccan Dutch teenagers use the words in limited contexts, for example to make fun of each other in online communication.

(3) $\mathrm{MM} / 5$ : $\underline{\text { Patas, }}$ wagi, skoro, oso, dat, meestal gebruiken we dat, niet zo heel vaak, maar gewoon op whatsapp af en toe.

MM/6: Ja, whatsapp soms.

$\mathrm{MM} / 6$ : Bij jouw oso.

'MM/5: patas (shoes), wagi (car), skoro (school), oso (house), that, usually we don't use that very often, just on whatsapp sometimes.

MM/6: Yes, whatsapp sometimes.

MM/6: At your oso (house).'

In (3), all words in italics have a Srana background.

When two other speakers were asked about the use of DSL they answered negatively with respect to their own language usage. However, they say that it is more typical of the Indigenous Dutch to use them.

(4) Int.: Gebruiken jullie die hier ook?

$\mathrm{MM} / 7$ : Nee, niet echt. 
MM/8: Mwa, Hollanders gebruiken die hier vaak, Marokkanen niet.

MM/7: Ja, wij praten gewoon Nederlands of Berbers met elkaar.

'Int.: Do you use them as well here?

$\mathrm{MM} / 7$ : No, not really.

MM/8: The Dutch use them often here, Moroccans don't.

MM/7: Yes, we just speak Dutch or Berber with each other.'

There are indications that gender may play a role in the way DSL is used. An interview with a young female speaker with an Arabic heritage background indicates that she makes a different use of DSL. Interestingly, during the interview this speaker used a form of Dutch without any DML or DSL (one could say, a more formal version) while a young male speaker who was present during the interview, also a Moroccan Arabic heritage speaker, had a strong Moroccan Dutch accent and frequently used Berber function and content words such as $q a$, a marker of present discourse relevance, ižžan 'one' and yzaa 'look' in otherwise Dutch speech. The female interviewee indicated that for girls, at least on the ideological level, using DSL is unproblematic.

(5) MF/1: Net als Rotterdamse Straattaal gebruiken ze hier ook echt heel veel. Int.: Ja?

MF/1: $\quad$ Ook al Marokkanen of Hollanders, dat boeit eigenlijk niet, maar dat gebruiken ze toch.

MM/9: Jij praat nu echt șsabun, jij (laughter)

MF/1: Wollah ma, wallah ma șsabun, al m'n vriendinnen, hier, je kan gewoon vragen.

Int.: Marokkaanse vriendinnen? Die gebruiken echt Rotterdamse woorden?

$\mathrm{MF} / 1: \quad J a$

Int.: Dus ze zeggen ook mi waka richting oso?

MF/1: Of, ja, faka waar ga je nou? Ik ga naar oso.

Int.: Oké, en doen de jongens dat ook?

MM/9: Af en toe man, niet $\underline{z}$ o veel.

'MF/1: Like Rotterdam street language they use it a lot here.

Int.: Yes?

MF/1: Whether Moroccans or Dutch, that doesn't matter, but they really use it.

MM/9: You are really talking nonsense now, you.

$\mathrm{MF} / 1$ : Certainly not, it is certainly not nonsense, all my female friends here, you can ask them.

Int.: Moroccan female friends? They really use words from Rotterdam? 
MF/1: Yes

Int.: So they say mi waka to oso (I am walking home)?

MF/1: Or, yes, faka (what's up) where are you going? I'm going oso (home).

Int.: $\quad \mathrm{OK}$, and do the boys do that as well?

MM/9: Sometimes man, not so often.'

Mi waka, faka and oso all have a Sranan background. Wollah ma 'certainly not' is common in both Berber and Moroccan Arabic. The Moroccan expression șsabun 'nonsense' (literally: 'soap') is also the nickname of a boy who was present just before the interview took place. $\mathrm{MM} / 9$, in the last turn, pronounces $z o$ 'so' in a typically Gouda Moroccan Dutch fashion with palatalization (Mourigh fc.).

\section{Enregisterment and locality}

In work on the localization of youth varieties the concept of enregisterment plays a central role (cf. Agha 2005). It is through this concept that one "explore[s] how sets of linguistic forms that are hearable or visible in an area can merge, in people's minds, into "dialects", and how these dialects get linked with particular spaces or geographies, viz. cities or regions" (Aarsæther et al. 2015: 254). Simultaneously, a linkage in the process is established between the linguistic form and a particular social meaning. In this way a particular style or way of speaking can become "a socially recognised register of forms" (Agha 2005: 231). Depending on the order of indexicality a form may then become part of a specific locality irrespective of its ethnic or social origins. A linguistic feature that originates from an ethnic group may become devoid of its original association and gain a more general acceptance and use, and it may in turn be relinked to a locality, e.g. to certain neighborhoods (cf. Cornips and de Rooij 2013).

In Gouda, a process of enregisterment with respect to DML can be identified. However, while the linking of local DML to Gouda is certainly a dynamic ongoing process, enregisterment, at least in Gouda, should be viewed within the framework of ethnic boundaries. That is, the Moroccan Dutch teenagers in Gouda clearly link their speech to the local identity as opposed to the larger urban identity (Rotterdam, Amsterdam). Meanwhile there is no delinking of ethnicity from their youth variety. This process is illustrated by the following excerpts, in which the relation between DML and DSL is discussed. The reader will notice that the two varieties are on different indexicality levels in the two relevant ethnic groups (i.e. Moroccan Dutch and 
Indigenous Dutch). For the Indigenous Dutch a second order indexicality can be ascribed to DSL in terms of Silverstein (2003), which means that "speakers notice the linguistic forms and attribute meanings to them that are shaped by ideologies" (Aarsæther et al. 2015: 255). At this second level, speakers "naturalize and ideologize the sociolinguistic associations (indexical relations) that they have registered at the first order" (Woolard 2008: 438). In third order indexicality other ideological values come to be linked with linguistic forms. In the Indigenous Dutch group it is not very clear what Straattaal refers to, except that it is "a way of talking on the street" especially with peers, i.e., a more vulgar version of the language used at home with the family. The Indigenous Dutch speakers in Gouda do not realize that many of the lexical items they use in Straattaal originate from DSL. As the following fragment shows, these words fall in the same category as the non-DSL curse word Godverdomme 'God damnit'.

(6) Int.: Gebruiken jullie wel eens Straattaal?

DM/1: Niet vaak, maar af en toe.

Int.: Onderling?

$\mathrm{DM} / 2$ : Ja, dan heb je zelf niet eigenlijk door.

DM/1: Ja, gewoon, dan gaat er zomaar wat uit zonder dat we het doorhebben.

Int.: Wat dan bijvoorbeeld?

DM/1: Ja, Godverdomme of zo, zulk soort dingen.

'Int. Do you ever use street language?

$\mathrm{DM} / 1 \quad$ Not so often, but sometimes.

Int. Among each other?

$\mathrm{DM} / 2$ Yes, but you actually do not realize.

$\mathrm{DM} / 1 \quad$ Yes, sometimes something just escapes without use realizing.

Int. Like what for example?

DM/1 Yes, like God Damnit, that kind of thing.'

A moment later the same speakers were asked whether they use Surinamese words. The answer is quite revealing in that one of the speakers claims he does not use those words. From this it can be inferred that these words are not associated with any specific (ethnic) group.

(7) Int.: Gebruiken jullie bijvoorbeeld ook veel Surinaamse woorden?

$\mathrm{DM} / 1$ : Nee.

$\mathrm{DM} / 2$ : Nee.

Int.: Ken je die woorden wel? 
DM/1: Ik weet wat het is, maar ik gebruik geen Surinaamse woorden.

Int.: $\quad$ Nee? (laughter) Bijvoorbeeld met vrienden of zo. Wagi of dat soort dingen?

DM/1: Ja! Wagi wel eens, maar dat is...niet vaak hoor.

Int.: Of $\underline{\text { mati, }}$ dat soort dingen?

DM/1: Ja, dat wel.

Int.: Want wat dacht jij dan dat ik bedoelde met Surinaamse woorden?

DM/1: Ja, beetje een aparte taal of zo. (laughter) Nee, maar wagi of mati dat wordt wel eens gezegd ja.

'Int.: Do you also use a lot of Surinamese words?

$\mathrm{DM} / 1$ : No.

$\mathrm{DM} / 2$ : No.

Int.: Do you know those words?

DM/1: I know what it is, but I do not use Surinamese words.

Int.: No? For example with friends? Wagi (car) and that kind of thing?

DM/1: Yes! wagi (car) sometimes, but that is...not so often.

Int.: Or mati (friend), that kind of thing?

DM/1: Yes, that I do.

Int.: What did you think I meant by Surinamese words?

DM/1: Yes, like a strange language or so. No, but wagi (car) and mati (friend) are said sometimes.'

The speakers then proceed to give some other examples of words they use, like swa 'friend' which originates from Papiamentu. This fragment illustrates that these words are part of the linguistic repertoire of the teenagers, while at the same time they are unaware of the ethnic origin of the lexemes. In other words, the original ethnic or multiethnic meaning has become delinked from the ethnic group and now occupies its own social space which encompasses broader social meanings in terms of indexicality (cf. Eckert 2008). One may hypothesize that this particular use of the DSL youth variety in Gouda is part of the larger youth variety in the Netherlands.

Interestingly, the same speakers have different comments with regards to DML words in their speech. In the fragment below, the DML words are evaluated on a different level from the DSL words. When asked for DML words the interviewee can easily identify the lexical items and he associates them with Moroccan Dutch. The speakers say the following about the way Moroccans speak:

(8) Int.: $\quad$ Kunnen jullie iets noemen? Ik weet wel iets maar...

$\mathrm{DM} / 2: \quad z z a m \partial \check{r}$ 


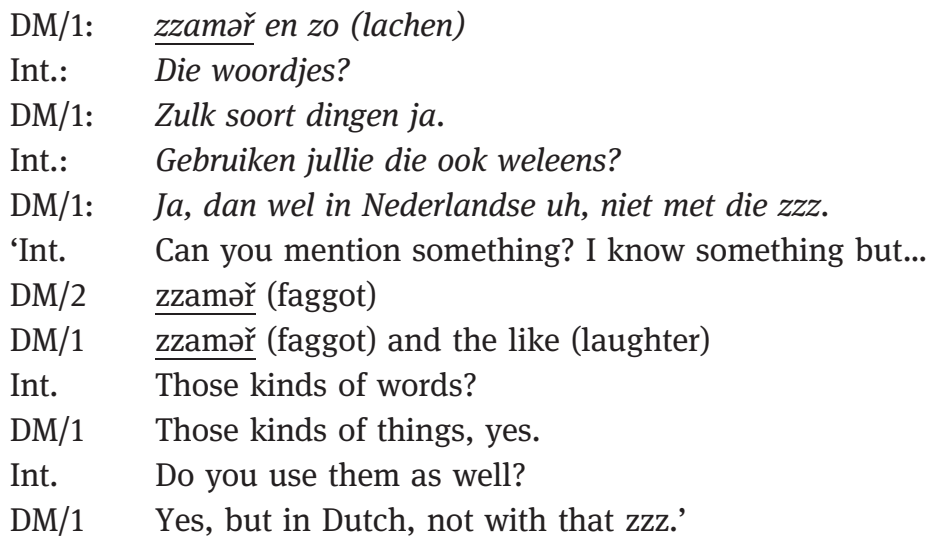

Speaker DM/1 is clearly aware of the origin of the lexical item and the way it is originally pronounced by its users, with the typical Moroccan voiced alveolar fricative which is geminated in this position (cf. van Meel 2016: 25-51). It reveals a high level of awareness of the particular linguistic and ethnic contact situation in Gouda.

The comments below by the Moroccan Dutch teenagers show a different picture. For them, DSL is ascribed a third-order indexicality as the speakers notice that for the users of DSL locality and ethnicity are "essentially linked" (Johnstone 2010: 164). In Agha's terms, it has not become enregistered as their variety of Straattaal. In fact, the Moroccan Dutch teenagers explicitly distance themselves from the "black" ethnic group. When asked about the usage of DSL, the Moroccan Dutch teenagers typically associate it with Surinamese, Antilleans or with "black people" in general. This constitutes a clear boundary marked through language between the in-group and the out-group. There is often a strong dissociation from DSL, which is associated with "blacks" in comments about attitudes of language form and function. In the following fragment the speaker uses swa 'friend' which is Papiamentu and not Sranan, which is an additional indication that "black" language is perceived as a monolithic unit.

(9) Int. : Gebruiken jullie Surinaamse woorden?

MM/10: Nee, joh, ben je gek? Dan slaan we elkaar kapot, als ik één keer hoor swa of zo, gelijk. We zijn geen zzwamər̆ a șahbi, we zijn geen negers.

'Int.: Do you use Surinamese words?

MM/10: No, man. Are you crazy? We beat each other up if I hear swa [friend] once, immediately. We are not faggots, my friend, we are not blacks.' 
The word swa 'friend' is originally Papiamentu. The expressions zzwamər̆ 'faggots' and a șahbi 'my friend' are Berber/Moroccan Arabic.

The speaker continues by sketching a possible situation in which two Moroccan Dutch teenagers meet each other. The use of DSL by a Moroccan Dutch teenager is frowned upon and the speaker conspicuously uses Berber in this case, as if he wants to stress the point that they are supposed to use Berber.

(10) MM/10: Hier, als je één keer zegt: iwa fawaka hoe gaat-ie? Ze kijken jou zo aan van: He, min tqawwad $\underline{\underline{d}}$ d?

'MM/10: 'Here, if you say: well, fawaka (what's up), how are you? They will look at you and say: Hey, what the hell are you doing?'

Fawaka 'what's up' is Sranan. Sentence-initial iwa has a Moroccan background (both Berber and Moroccan Arabic), while min tqəwwadod is Berber.

In another interview with another speaker a similar statement is repeated. This speaker switches to Berber in order to endorse his viewpoint.

(11) $\mathrm{MM} / 2$ : Wij hebben niet echt gewoon die Straattaal, net als, je weet toch wel, die Antillianen en zo.

Int.: $\quad$ Maar als er een Marokkaan die hiervandaan komt Surinaams gaat praten van, "he faka G, ga je wroko, ga je skoro?"

MM/2: $\quad$ We lachen die mensen, dan lachen we die mensen uit. kkaa a tặ a tqawwdod a buyizzan, zo, dat is onze reactie, a kkaa a tah a

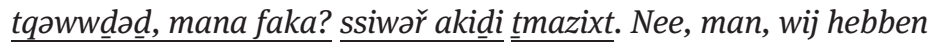
dat niet. Die faka, skoro, tranga.

'MM/2: We don't really have that street language, you know, like Antilleans etc.

Int.: But if a Moroccan who is from here starts speaking Surinamese like "Hey faka (what's up) G? Are you going (to) wroko (work)? Are you going (to) skoro (school)?”

MM/2: We laugh at those people get out of here, you shithead, like that, that would be our reaction: Get the hell out of here, what faka (what's up)? Speak Berber to me. No, we don't use that, that faka (what's up), skoro (school), tranga (awesome).

Faka, wroko and skoro have a Sranan background, while tranga has a Papiamentu origin. $G$ is an American slang abbreviation of gangster. All the other non-Dutch elements are Berber.

Individuals (or groups) can express their presence through spatial references (cf. de Haan 2005). In the case of the Moroccan Dutch teenagers in Gouda the 
inhabited space is linked to Moroccan Dutch ethnicity. A similar process is discussed by Cornips and de Rooij (for a Surinamese teenager) in which "the opposition between self and other by means of place is applied recursively (Gal and Irvine 1995), i.e., within the category Surinamese." (Cornips and de Rooij 2013: 157). Through this process of Selfing and Othering the speakers distance themselves from the big city; an instance whereby not only a language variety is Othered, but the locality to which the Other belongs as well. Through this process, the Self, their own group and locality is firmly established. In this dialectic process DSL is associated with negers 'blacks', but is used as well by Moroccan Dutch teenagers living in the big city, pointing to a division between the ideological level (black language) and a practical level (usage by Moroccan Dutch teenagers in Amsterdam).

(12) Int.: $\quad$ Maar gebruiken jullie ook Straattaal en zo?

MM/11: $\quad 0$, die ene faka $G$ en zo? Nee, joh! Vooral in Amsterdam zijn, alleen maar Marokkanen, mijn neef ook en zo, die praten alleen maar die ene negertaal en zo.

'Int.: Do you also use Straattaal etc?

MM/11: Oh, like faka G (what's up G) etc? No, man! Especially in Amsterdam, Moroccans, my cousin etc, they speak that black language all the time.'

In another interview a speaker distances himself from Rotterdam. The variety spoken there is not accepted either. Moroccan Dutch teenagers who live in the big cities transgress the boundaries of how a Moroccan Dutch teenager from Gouda should speak by the way they adopt the "black" way of talking. This provokes an aggressive reaction on the part of one respondent:

(13) Int.: Maar als je naar Rotterdam gaat, veel Marokkanen....

MM/ Ja, nou, met die Rotterdammers, soms ja, zeggen ze fawaka dit, faw,

10: $\quad$ kkaa a tnoggzad, kkaa a tnaggzad xafi met je fawaka, a š fawakay hier op je neus. tozz.

'Int.: But when you go to Rotterdam, a lot of Moroccans...

MM/ Yes, well, those people from Rotterdam say fawaka (what's up)

10: this, go away man, go away from me with your fawaka (what's up), I will fawaka (what's up) you here on your nose. yuck.'

In (13), Fawaka 'what's up' is Sranan. All the other phrases are in Berber. Note the way the speaker jokingly turns fawaka into a verb by adding inflection ( $a \check{s}$ fawakay 'I will fawaka you').] 
In another comment an example is given from boys from Gouda who attend school in Rotterdam, and subsequently start using DSL. It is not considered problematic if someone goes to school there, and there is no comment about that whatsoever. However, again, the speaker indicates that a person should not transgress the boundary of the local Gouda Moroccan Dutch identity, displaying multiple layers of identification.

(14) Int.: Dus dat Surinaams is minder hier?

MM/2: Als bijvoorbeeld, sommige jongens, je weet toch, ze zitten daar op school. Je zegt tegen ze: iwa waar ga je morgen naartoe dan? Zeggen ze tegen mij: "Ik moet naar skoro man" of van "ik moet naar Roffa”. "Iwa kifaš šəkk a șaḥbi”, je weet toch, dat isonze reactie, "twee dagen Rotterdam, șafi niy?"

'Int.: So Surninamese is less common here?

$\mathrm{MM} / 2$ : If for example, some guys, you know. They go to school there. You tell them: so where are you going tomorrow? They tell me: "I have to go to skoro (school) man" or "I have to go to Roffa (Rotterdam)". "Well, what is the matter with you, friend", you know, that is our reaction, "two days in Rotterdam, and it's over, or what?"'

In (14), skoro is Sranan, while Roffa 'Rotterdam' is a specific “straattaal” word, clearly associated with DSL, at least by MM/2. The other underlined non-Dutch words and phrases are Berber.

One could draw the conclusion that a difference in the level of indexicality is clearly present in the two major ethnic groups. It is a process that has been described before in other situations in which indexicality is not a linear process, either historically nor synchronically, but rather it is "a multi-layered field of associations” (Aarsæther et al. 2015: 255; Johnstone et al. 2006; Johnstone and Kiesling 2008). DML is clearly associated with Moroccan Dutch teenagers by both groups, while DSL is not associated with black ethnicities by the Indigenous Dutch, but it clearly is by Moroccan Dutch respondents.

DML has become locally associated, meanwhile it has not reached the level in which it has become "de-ethnified", i.e. both groups associate the use of DML with the Moroccan Dutch ethnic group which, undoubtedly, entails further social meanings that are stereotypically associated with that particular ethnic group. What exactly those associations are, how they can be understood and interpreted remains a question for further research. A multiethnolect understood as a shared way of speaking across ethnic boundaries certainly exists for the Dutch, however for the Moroccan Dutch youth there are clear ethnic boundaries 
in language use, and consequently in the language variety they associate themselves with.

\section{Borrowing: Berber lexicon}

The variety used in Gouda mostly draws on the main heritage language Berber. When the heritage speakers of Berber use DML items it is impossible to distinguish a youth variety status from code-switching. Therefore, it is difficult to identify a separate youth variety for speakers who have a certain level of knowledge of the heritage language, since code-switching always remains an option and in fact does occur sometimes as shown in some of the examples above. However, there are good reasons to consider some Berber lexical elements as part of the youth variety. One argument, as discussed above, is the frequent occurrence of a limited set of lexical items. A second argument is that Moroccan Arabic heritage speakers use Berber elements, as mentioned in Section 3. These facts run counter to a code-switching account, and one can safely assume that the elements adopted have gained the status of a youth variety within the Gouda Moroccan Dutch community. A case in point is the following Arabic heritage speaker who is asked to give an example of Gouda Moroccan Dutch speech. The example is in Dutch with the insertion of a Berber word.

(15) $\mathrm{MM} / 3$ : Wat ga je doen a zzaməř vanavond? žo.

'What are you going to do a zzaməř (oh faggot) tonight? Like that.'

In (15), a zzamər with the vocative particle $a$ and the noun zzamər 'faggot' is Berber. The speaker also uses the typical Gouda Moroccan pronunciation žo instead of $z o$.

Arabic heritage speakers take over some Berber elements incorrectly into their Dutch discourse. An example is the following excerpt in which an Arabic heritage speaker uses the Berber presentative element $a \gamma$-aš 'here you go' instead of the element aqqa-š which would have been correct. ${ }^{7}$

(16) MM/1: Eén keer we zaten bij big Mo film te, televisie te kijken, Barcelona of zo speelde, toen zei ik: $\underline{a \gamma-a s ̌}$ adiesta, ik bedoelde Iniesta, wist ik veel hoe die heette a șahbi.

7 The difference is that $a \gamma$-aš would be used when handing something over physically, while $a q q-a s ̌$ is used for directing attention to something. This is a significant difference for speakers of Tarifiyt Berber. 
'MM/1: Once we were watching television at big Mo's, Barcelona I think was playing, then I said: here you have Adiesta, I meant Iniesta, I didn't know his name, my friend.'

Furthermore, the Moroccan Dutch teenagers observe DML is taken over by the Indigenous Dutch on both lexical and phonetical levels, as illustrated in (17):

(17) $\mathrm{MM} / 12$ : $\quad$ Nederlanders beginnen ook steeds meer Straattaal, joh, beginnen steeds meer op Marokkanen te lijken. Die zeggen ook qawwad en hawař en zaßma.

Int.: $\quad$ Gebruiken sommige Nederlanders ook "řo"?

MM/12: Ja, sommige zijn aan het oefenen.

MM/1: We hebben ze zeg maar gewoon, we hebben onze software op hun gezet (lachen), dat is, zo kun je het bekijken, șafi, ze hebben onze software overgenomen.

'MM/12: The Dutch are also beginning with Straattaal, they seem more and more like Moroccans. They also say, qəwwəd (piss off) and hawəř (watch out) and zəSma (like).

Int.: $\quad$ Do some Dutch also use žo (like that)?

MM/12: Yes, some are practicing.

MM/1: We have planted our software on them (laughter), you can look at it like that, that's it, they took on our software.'

The words qəwwəd, hawař and zəSma in (17) are Berber. The pronunciation of Dutch $\check{z}$ instead of $z o$ is a typically Gouda Moroccan way of pronouncing.

The next example shows that Indigenous Dutch know which words are of Moroccan origin and are even aware of the fact that they pronounce the words differently. It is not clear whether this type of language practice can be qualified as a type of language crossing in the sense of Rampton (1995, 1998). While the latter type of practice entails a "movement across quite sharply felt social or ethnic boundaries" (Rampton 1998: 1), there is no evidence for it as a stylized variant or mimicking of another group's variety (cf. Coupland 2007; Jaspers 2004). Rather, the DML elements are adopted in particular ways by the Indigenous Dutch group. One speaker says that oso 'house' and wagi 'car' (DSL items) are used, but he explicitly confirms that it is part of Straattaal, which according to his comment encompasses a much wider cluster of lexical items for the speaker.

(18) Int.: Spreken jullie Straattaal zelf?

$\mathrm{DM} / 3$ : Het is maar wat je Straattaal noemt.

$\mathrm{DM} / 4$ : Ik denk het wel. 
Int.: Maar wat is Straattaal dan? Want je zegt: het is maar wat je Straattaal noemt.

DM/3: Ja, ik weet niet hoe je dat uit kan leggen, het is gewoon Nederlands maar dan met allemaal gekke woorden er tussendoor.

Int.: Zoals?

DM/3: Ik kan er niet even geen voorbeeld van noemen.

Int.: Zijn dat dan scheldwoorden of zo?

DM/3: Soms wel ja.

Int.: $\quad$ Maar zijn dat Surinaamse woorden of Engels of zo?

$\mathrm{DM}$ /4: Van alles en nog wat, denk ik.

DM/3: Zeg maar alsof je alles op straat gooit en er doorheen veegt tot éen hoopje.

Int.: Maar bijvoorbeeld chi-meid of zo?

DM/3: Dat gebruik ik zelf nooit.

Int.: $\quad \underline{\text { oso? }}$ ?

DM/3: Ja.

Int.: en wagi?

DM/3: Ja, als ik een wagi had (lachen).

Int.: Maar dat bedoel je met Straattaal?

DM/3: Ja, ongeveer.

'Int.: Do you speak Straattaal yourself?

DM/3: It depends on what you mean by Straattaal.

$\mathrm{DM} / 4$ : I think so.

Int.: But what is Straattaal? Because you say: It depends on what you mean by Straattaal.

DM/3: I don't know how to explain it. It is Dutch mixed with all kinds of weird words.

Int.: Like?

DM/3: I can't think of an example now.

Int.: Are they cursing words or?

DM/3: Sometimes yes.

Int.: But are they Surinamese words or English or what?

DM/4: All kinds of things, I think.

$\mathrm{DM}$ /3: It is like you throw everything on the street and sweep through it until it becomes one pile.

Int.: But for example chi-girl (attractive girl) or so?

DM/3: I never use that myself.

Int.: $\quad$ oso (house)

DM/3: Yes

Int.: and wagi (car)? 
DM/3: Yes, if I had a wagi (car) (laughter).

Int.: That is what you mean by Straattaal?

DM/3: Yes, approximately.'

In (18), oso and wagi are Sranan, while chi probably stems from the Sranan word for 'small'. In combination with meid ('girl') it resembles the Dutch word for girl "meisje" which is a diminutive form.

As the conversation continues, some interesting information about transfer and use of a DML function word is revealed. It appears that within the classification of Straattaal words, a combination of lexical items from different unknown sources, the DML elements are on a separate identifiable level.

(19) Int.: Ook Marokkaanse woorden?

DM/3: Ja.

Int.: Kun je bijvoorbeeld iets noemen?

$\mathrm{DM} / 3: \quad J a$, wola. (lachen). ${ }^{8}$

Int.: Hoe gebruiken jullie dat dan?

DM/3: Nou, als mensen iets gaan zeggen en je bent het er mee eens, dan zeg je gewoon: ja, wola. (laughs). Iemand ging dat de hele tijd zeggen, vonden we allemaal zo dom en nu zeggen we het allemaal.

Int.: Maar zeg je dan: wola hij is dom?

DM/3: Nee, dat niet. Dat doen meer de Marokkanen bij ons.

Int.: Dus jullie gebruiken het op een andere manier dan de Marokkanen? DM/3: Ja.

'Int.: Moroccan words as well?

DM/3: Yes

Int.: Can you give an example?

DM/3: Yes, wola (lo!). (laughter)

Int.: How do you use that?

DM/3: Well, if people say something and you agree, you say: yes, wola (lo!). Somebody said that all the time, we thought it was stupid and now we all say it.

Int.: But do you say: wola (lo!) he is stupid.

DM/3: No, we don't. That's what the Moroccans do here.

Int.: So you use it in a different way from the Moroccans? ${ }^{9}$

DM/3: Yes.'

8 This is the equivalent of Berber/Arabic wollah. The spelling has been changed to match the pronunciation more precisely.

9 In Berber/Arabic wallah is not only used as an element on its own, but in embedded sentences as well. 
Both the pronunciation and the use of Berber/Moroccan Arabic wallah are different, even though $\mathrm{DM} / 3$ is well aware of its Moroccan background. The point is that in Berber/Moroccan Arabic wallah is not just an interjection standing on its own, but can be used to modify the following utterance.

This fragment further suggests that DML words are spreading. In addition, it displays one of the possible boundaries, routes and limits in which a lexical item can be appropriated: a new word is used by one speaker, an element that originates from a group that is known to have covert prestige. Then the element is used by one speaker which one could imagine to be "funny", "stupid" or "backward". The laughter accompanying this statement points to a funny, not-so-serious way of talking, a possible meaning that is indicative of the connotation that usage of DML may have. The next step is that the DML element spreads through this small community of practice. A major difference is that the element is not a one-to-one copy from DML, it is not embedded in a phrase and only used as a free element, signaling that the speaker is conscious of the difference of the relevant Other. There are limits to what the Indigenous Dutch take over, an observation that was confirmed by a Moroccan Dutch teenage girl when asked about the use of the question particle waf by Indigenous Dutch teenagers.

(20) Int.: Maar gebruiken jullie bijvoorbeeld ook "waš heb je die mannetje gezien?" of zo?

MF/1: Ja ook (laughter), wij altijd. Waš heb je die gezien?

Int.: $\quad J a$.

$\mathrm{MF} / 1$ : Ja, dat is echt erg.

Int.: En dit soort dingen. Nemen Nederlands dit wel over?

MF/1: Nee, die waš echt niet.

'Int.: But do you use for example "waš have you seen that guy?" or the like?

MF/1: Yes, also (laughter), we always do. Waš have you seen him?

Int.: Yes.

MF/1: Yes, that is really bad.

Int.: And these kind of things. Do the Dutch copy them?

MF/1: No, that waš, they really don't.'

As (20) illustrates, the Moroccan Arabic question particle waš is regularly used in Moroccan Dutch contexts. It marks the phrase as a yes/no question. 


\section{Conclusion}

On the level of linguistic practice, it is clear from this discussion that there exists a DML based youth variety in Gouda with a restricted set of lexical items. Moroccan heritage language speakers use Berber in their youth variety, some elements of which have spread (or are spreading) to Indigenous Dutch speakers. There is a limited use of DSL lexicon in Gouda, which seems to be more accepted by the Indigenous Dutch than by the Moroccan Dutch youth. An interesting difference is the level of indexicality ascribed to the DSL items: the Moroccan Dutch young people have a much higher awareness of the source language of the words than Indigenous Dutch; a source from which they typically strongly dissociate themselves. Furthermore, a process of enregisterment of locality has been identified, which puts Gouda and its Moroccan Dutch youth on a level different from the large multiethnic cities Amsterdam and Rotterdam. A boundary is created by "our” way of youth speech and "their" way of youth speech, the latter being simultaneously associated with "black" speech.

The examples presented have also demonstrated that metalinguistic comments can provide insight into language practices and ideologies which would have been much more difficult to uncover using other methods. Usually, interviews suffer from the observer's paradox and succeed therefore only partly in capturing natural data. To be sure, it remains essential to combine research approaches, each having its own merits. The metalinguistic comments add language ideologies and practices to the "total linguistic fact", which would otherwise possibly have remained hidden. In the context of this research they give the researcher clues as to the boundaries, routes and limits of language contact and spread.

In summary, a multiethnolect where DSL and DML are combined does not exist in Gouda for the Dutch with a Moroccan heritage background. The data presented have shown that it is important to compare existing language ideologies and practices of different ethnic groups. That is where one finds great and relevant differences. Without wishing to reify ethnic groups which have contested, flexible and multi-layered identities - it is clear that from the local linguistic perspective of Gouda, there is ample evidence that ethnicity should not be discarded as a relevant factor in sociolinguistic studies on Dutch youth varieties. The findings based on metalinguistic comments can give the researcher a significant and even crucial insight into the dynamics of youth varieties. 


\section{References}

Aarsæther, Finn, Stefania Marzo, Ingvild Nistov \& Evy Ceuleers. 2015. Indexing locality: contemporary urban vernaculars in Belgium and Norway. In Jacomine Nortier \& Bente A. Svendsen (eds.), Language, Youth and Identity in the 21st Century. Linguistic Practices across Urban Spaces, 249-270. Cambridge: Cambridge University Press.

Agha, Asif. 2005. Voice, footing, enregisterment. Journal of Linguistic Anthropology 15(1). 38-59.

Aissati, Abderrahman el, Louis Boumans, Leonie Cornips, Margreet Dorleijn \& Jacomine Nortier. 2005.Turks- en Marokkaans-Nederlands [Turkish- and Moroccan-Dutch]. In Nicoline Van Der Sijs (ed.), Wereld Nederlands. Oude en jonge variëteiten van het Nederlands [World Dutch. Old and new varieties of Dutch], 149-183. Den Haag: SDU.

Appel, René. 1999. Straattaal. De mengtaal van jongeren in Amsterdam [Straattaal. The mixed language of youth in Amsterdam]. Toegepaste Taalwetenschap in Artikelen 62. 39-55.

Appel, René \& Rob Schoonen. 2005. Street language: a multilingual youth register in the Netherlands. Journal of Multilingual and Multicultural Development 26(2). 85-117.

CBS. 2016. Centraal Bureau voor de Statistiek [Central Statistics Office]. www.cbs.nl (27 October 2016).

Cheshire, Jenny, Jacomine Nortier \& David Adger. 2015. Emerging multiethnolects in Europe. (Queen Mary's Occasional Papers Advancing Linguistics 33). London: Queen Mary University London.

Cornips, Leonie \& Vincent de Rooij. 2013. Selfing and othering through categories of race, place, and language among minority youths in Rotterdam, The Netherlands. In Peter Siemund, Ingrid Gogolin, Monika Schulz \& Julia Davydova (eds.), Multilingualism and language diversity in urban areas: acquisition, identities, space, education (Hamburg studies on linguistic diversity, 1), 129-164. Amsterdam: John Benjamins.

Coupland, Nikolas. 2007. Style: Language variation and identity. Key Topics in Linguistics. Cambridge, New York: Cambridge University Press.

Dorleijn, Margreet, Maarten Mous \& Jacomine Nortier. 2015. Urban youth speech styles in Kenya and the Netherlands. In Jacomine Nortier \& Bente A. Svendsen (eds.), Language, Youth and Identity in the 21st Century. Linguistic Practices across Urban Spaces, 271-289. Cambridge: Cambridge University Press.

Eckert, Penelope. 2008. Where do ethnolects stop? International Journal of Bilingualism 12(1). 25-42.

Gal, Susan \& Judith Irvine. 1995. The boundaries of languages and disciplines: How ideologies construct difference. Social Research 62. 967-1002.

Haan, Henk de. 2005. Social and material appropriation of neighborhood space: Collective space and resistance in a Dutch Urban Community. In Marco Van Der Land \& Leeke Reinders (eds.), Doing, Thinking, Feeling Home: The Mental Geography of Residential Environments. (Proceedings of the International ENR Conference, Delft, 14-15 October 2005), 1-26. Delft: University of Technology: OTB.

HCP. Haut-Commissariat au plan. 2016. http://www.hcp.ma/Recensement-general-de-la-popu lation-et-de-l-habitat-2004_a633.html (27 October 2016).

Jaspers, Jürgen. 2004. Tegenwerken, belachelijk doen. Talige sabotage van Marokkaanse jongens op een Antwerpse middelbare school. Een sociolinguïstische etnografie. [Sabotage, 
acting ridiculous. Linguistic sabotage by Moroccan boys in an Antwerp secondary school. A sociolinguistic ethnography]. Antwerpen: Universiteit Antwerpen.

Johnstone, Barbara. 2010. Language and geographical space. In: Peter Auer \& Jürgen E. Schmidt (eds.), Language and Space: An International Handbook of Linguistic Variation, 1-18. Berlin \& New York: Mouton de Gruyter.

Johnstone, Barbara, Jennifer Andrus \& Andrew E. Danielson. 2006. Mobility, Indexicality, and the Enregisterment of "Pittsburghese." Journal of English Linguistics 32(4). 77-104.

Johnstone, Barbara \& Scott F. Kiesling. 2008. Indexicality and Experience: Variation and Identity in Pittsburgh. Journal of Sociolinguistics 12(1). 5-33.

Kossmann, Maarten. fc. Is Dutch Straattaal a mixed multiethnolect? A Moroccan perspective. Applied Linguistics Review.

Lemon, Alaina M. 2002. Form and Function in Soviet Stage Romani: Modeling Metapragmatics through Performance. Language in Society 31(1). 29-64.

Lier, Eva van. 2004. Straattaal [Street language]. Neerlandica Extra Muros. Tijdschrift van de Internationale Vereniging voor Neerlandistiek. 43(1). 12-26.

Meel, Linda van. 2016. The Roots of Ethnolects. A Sociophonological Study in Amsterdam and Nijmegen. (Ph.D. dissertation). Nijmegen: Radboud Universiteit.

Montrul, Silvina. 2016. The Acquisition of Heritage Languages. Cambridge, UK: Cambridge University Press.

Mourigh, Khalid. fc. Sibilant Palatalization in Gouda Moroccan Dutch. Nederlandse Taalkunde.

Muysken, Pieter. 2013. Ethnolects of Dutch. In Frans Hinskens \& Johan Taeldeman (eds.), Language and Space: Dutch, 739-761. Berlin: Mouton de Gruyter.

Nortier, Jacomine. 2001. Murks en Straattaal. Vriendschap en taalgebruik onder jongeren [Murks and street language. Friendship and language use among youngsters]. Amsterdam: Prometheus.

Nortier, Jacomine \& Margreet Dorleijn. 2008. A Moroccan accent in Dutch: a socio-cultural style restricted to the Moroccan community? International Journal of Bilingualism 12(1-2). 125-143.

Nortier, Jacomine \& Margreet Dorleijn. 2013. Multi-ethnolects: Kebabnorsk, Perkerdansk, Verlan, Kanakensprache, Straattaal, etc. In Peter Bakker \& Yaron Matras (eds.), Contact Languages, 237-270. Berlin \& New York: Mouton de Gruyter.

Rampton, Ben. 1995. Crossing: Language and Ethnicity among adolescents. Real language series. London \& New York: Longman.

Rampton, Ben. 1998. Language crossing and the redefinition of reality. In Peter Auer (ed.), Codeswitching in Conversation, 290-320. London: Routledge.

Ruiter, Jan Jaap de. 1989. Young Moroccans in the Netherlands: An Integral Approach to their Language Situation and Acquisition of Dutch. (PhD Thesis). Utrecht: Universiteit Utrecht.

Silverstein, Michael. 1985. Language and the culture of gender: at the intersection of structure, usage, and ideology. In Elizabeth Mertz \& Richard Parmentier (eds.), Semiotic mediation: Sociocultural and psychological perspectives, 219-259. Orlando: Academic Press.

Silverstein, Michael. 2003. Indexical order and the dialectics of sociolinguistic life. Language and Communication 23(3). 193-229.

Woolard, Kathryn A. 2008. Why dat now? Linguistic-anthropological contributions to the explanations of sociolinguistic icons and change. Journal of Sociolinguistics 12(4). 432-452. 